\title{
CELL-LINED, NONWOVEN MICROFIBER SCAFFOLDS AS A BLOOD INTERFACE *
}

\author{
William E. Burkel and Raymond H. Kahn \\ Department of Anatomy \\ University of Michigan \\ Ann Arbor, Michigan 48104
}

In order to provide blood-compatible interfaces for artificial vascular prostheses, technology has proceeded along several lines, including the use of (1) synthetic materials such as neutral, ionic and polarized polymers and pyrolytic carbons; (2) additive containing materials such as heparin; (3) hydrogels; (4) woven and nonwoven fiber scaffolds lined with cells or fibrin; and (5) composites of the above. ${ }^{1,2}$ Although fiber scaffolds (in the form of porous woven or knitted fabrics) have been in use for many years, healing is somewhat capricious and is always preceded by the formation of a fibrin coagulum that subsequently undergoes organization and may or may not give rise to a healed endothelium. The use of porous prostheses permits flexion of the vessel as well as adherence of the fibrin coagulum and the potential for transinterstices growth of tissue, which, it is hoped, will lead to a healed pseudointima. Since adherence of the pseudointima (whether cellular or fibrin) and healing depends to a great extent on the surface characteristics and porosity of the prosthesis, ${ }^{3-11}$ many types of surfaces have been developed (woven, knitted, velours, flocks, lattices, etc.) to promote better healing. Emphasis recently has been on the production of prostheses with smaller fibers and pores such as "Weavnit," 9 "Microknit," 10 and "Warpknit" 11 for clinical application. On the experimental side, in recent years nonwoven microfiber scaffolds have been produced ${ }^{12-1.4}$ as an alternative to woven and knitted prostheses.

Heart-assist devices must of necessity be nonporous, given the nature of the pneumatic pumps. Since blood pumps have large surfaces exposed to the blood, the potential for thrombus, degradation of blood proteins, and hemolysis is great. To circumvent these problems, fabric-lined pumps have been developed. ${ }^{15-20}$ However, such nonporous prostheses or pumps permit no growth of cells except from the natural vessel at the anastomotic line. Since this neointima comes only from the intima or media of the vessels at the suture line in both heart assists or in arterial grafts, ${ }^{21}$ production of cellular pseudointimas before implantation of the devices would be beneficial.

Various methods of pseudointima production have been attempted, including: (1) the use of tissue fragments, ${ }^{16,19,20}$ (2) trypsinization of organs, viscera, and so on, followed by immediate seeding of prostheses with dispersed cells, ${ }^{20}$ ( 3 ) derivation of cells from tissues followed by cultivation in vitro and seeding of subcultured cells. ${ }^{20,22-31}$ Numerous cell sources for culture-derived pseudointimas have been tried, including skin, ${ }^{17,20}$ kidney, ${ }^{20},{ }^{24}$ arteries, ${ }^{20}$ veins, ${ }^{19,20,22}$ subcutaneous tissue, ${ }^{19,20}$ lung, ${ }^{16,20}$ pleura, ${ }^{22}$ fascia, ${ }^{22}$ granulation tissue, ${ }^{19,20,22,28}$ bone marrow, ${ }^{19}$ macrophages, ${ }^{13}$ pericardium, ${ }^{20,}{ }^{22}$ fibro-

* Supported by contract no. NIH-NO1-HB-2054 from the National Heart and Lung Institute, National Institutes of Health, Bethesda, Md. 20014. 
blasts, ${ }^{23,} 24,28$ buffy coat, ${ }^{25}$ endothelial cells, ${ }^{18,22,25,26,30,32,33,35}$ smooth muscle $^{35}$ skeletal muscle, ${ }^{16,19,20}$ ascitic cells, ${ }^{19}$ epidermis, ${ }^{26,}{ }^{29}, 31-33$ WI-38 cells, ${ }^{25-29,31-33}$ and urothelium).$^{29}$

This paper reports some of our experiences on the development of pseudointimas on nonwoven microfiber scaffolds with cells derived from human tissue, namely, WI-38, epidermal, endothelial, and urothelial cells.

\section{Materials AND Methods}

\section{Cell Sources}

Diploid WI-38 cells derived from embryonic human lung were obtained from Professor L. Hayflick of Stanford University at approximately the twelfth passage. These cells were used to screen microfabrics for biocompatibility and to develop techniques for producing pseudointimas. Human epidermal cells were obtained from split-thickness skin explants obtained from the University of Michigan Dermatology Clinic. Endothelium was surgically derived from stripped veins, aneurysmectomy, and normal veins of kidney-transplant cadavers. Urinary tract epithelium, which we have referred to as urothelium, was obtained from biopsies of urethra, bladder, and renal pelves.

Epidermal, endothelial, and urothelial cells were isolated by treatment of the corresponding explants with $0.25 \%$ trypsin and 1\% EDTA in balanced salt solution (Earle's calcium and magnesium-free, 1X, Grand Island Biological Company). After incubation of the explants for $15-20$ minutes at $37^{\circ} \mathrm{C}$ in the above solution, the epithelial layer was gently teased off from the underlying connective tissue and transferred to growth medium in Faicon plastic tissue culture flasks. Growth medium consisted of Eagle's Basal Medium (BME, cat no. G13, Grand Island Biological Company) buffered with 0.10 M HEPES ${ }^{36}$ (N-2 hydroxyethyl piperazine sulfonic acid, California Biochemical Corp.),

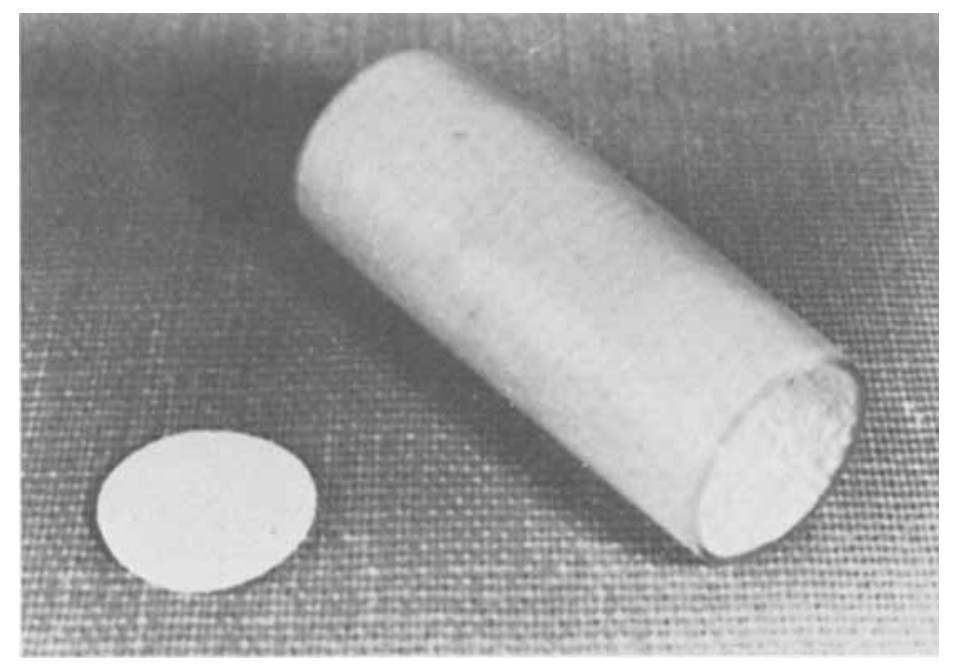

Figure 1. Tube and disc of the type used for compatibility testing and pseudointimal development. $\times 1.5$. 


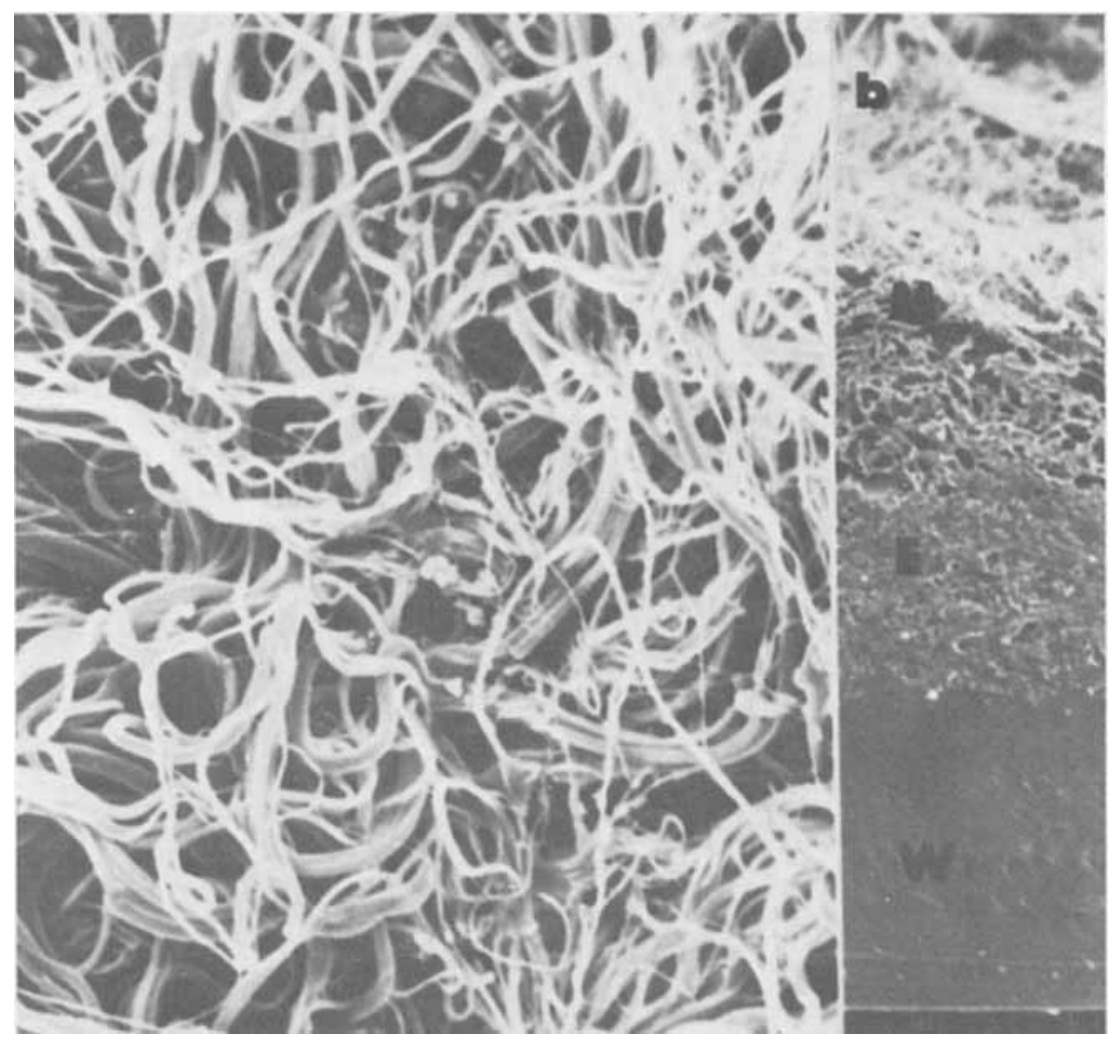

Figure 2. Polyester (polytetramethylene terephthalate) microfiber scaffold produced by hot-melt extrusion. $a=$ Microfabric surface $(\times 380) ; b=$ cross section of tube showing embeddment (E) of microfibers $(M)$ into nonporous estane wall (W) $(\times 130)$.

buffered to $\mathrm{pH} 7.4$ at room temperature. The medium was supplemented with $10 \%$ bovine serum and $50 \mu \mathrm{g} / \mathrm{ml}$ Aureomycin Chlortetracycline $\mathrm{HCl}$ (Lederle Division, American Cyanimide Corp.)

\section{Microfabrics}

Polyurethane $(5714-\mathrm{F} 1$ estane) tubes $(18 \times 50 \mathrm{~mm})$ and discs $(15 \mathrm{~mm}$ in diameter) lined with microfiber scaffolds of nylon 6,6 , carbon-coated nylon, polyester(polytetramethylene terephthalate), and polypropylene were used in these studies (FIGURE 1). Nylon 6,6 and polyester microfibers were produced by hot melt extrusion to give a nonwoven microfiber mesh of $0.2-2 \mu \mathrm{m}$ fibers bonded to the nonporous estane by a negative casting procedure ${ }^{12}$ by Abcor Corporation, Cambridge, Mass. (FIgure 2). Some of the nylon was coated with a $3000 \AA$ layer of pyrolytic carbon ${ }^{36,37}$ by Gulf Atomic Corporation, San Diego, Calif. or Parylene-C, ${ }^{1,}{ }^{39}$ and microwave discharge-treated. Polypropylene (Union Carbide, Inc., Boundbrook, N.J.) microfibers were produced by 
coextrusion of polypropylene and acrylic copolymers followed by extraction of the acrylic component and stretching or horizontal drafting of the extruded tape. ${ }^{14,40}$ The resulting fibers were $0.2-2 \mu \mathrm{m}$ in diameter and were supplied in two configurations, a nonvertically drafted fiber mat produced by horizontal drafting only, and a vertically drafted fiber mat produced by horizontal and vertical drafting (FIGURE 3 ). These were attached to estane tubes and discs ${ }^{41}$ and were coated with a $5000 \AA$ layer of Parylene-C. All tubes and discs were sterilized by beta radiation.

\section{Preparation of Pseudointimas}

Pseudointimas were produced by a four-step process $27,29,32$ which included (1) washing and degassing of fabric, (2) seeding of cells, (3) stabilization, and (4) static or perfusion culture. Prior to seeding with cells, the tubes or discs were washed and degassed in media at low negative pressures $(10-15 \mathrm{~mm} \mathrm{Hg}$ ). The cell sources, propagated as monolayer cultures, were trypsinized $(0.25 \%$ in balanced salt solution), washed in balanced salt solution, and seeded with an appropriate number of cells to give approximately $2000-10,000$ cells $/ \mathrm{mm}^{2}$ of fabric surface. Seeding of tubes and discs was accomplished by centrifugation of cells into the fabric at about $50 \times g$ for approximately one minute. Emigration of the cells from the fabric was prevented by "stabilization" of the tube or disc in a confined environment for about 12 hours. After stabilization, the tubes were placed in a modified New Brunswick Rollacell perfusion apparatus and cultivated for six days. Tubes were rotated at 11 revolutions per hour and perfused for 5-10 seconds every hour, depending on the glucose content of the effluent medium. Discs were cultivated under static conditions in T-75 Falcon tissue-culture flasks for a corresponding amount of time, with media changes every two days.

\section{Evaluation}

Tubes and discs were evaluated by light microscopy and scanning and transmission electron microscopy. Samples were fixed in $2.5 \%$ glutaraldehyde and $0.1 \mathrm{M}$ cacodylate buffer at $\mathrm{pH} 7.4$ followed by postosmication and dehydration in a graded series of alcohols. Samples for light microscopy and transmission electron microscopy were embedded in Epon, cut at $1 \mu \mathrm{m}$ and stained with methylene blue. Selected samples were thin-sectioned and stained with uranyl acetate and lead citrate for transmission electron microscopy. Corresponding samples were prepared for scanning electron microscopy by freeze- or criticalpoint drying followed by gold or gold-paladium coating. Pseudointimas were evaluated by estimating the percentage of surface area of the tube or disc covered with cells when observed with the scanning electron microscope. Penetration of fabric by cells and cell-fabric relationships were studied by light and transmission electron microscopy.

\section{RESULTS}

\section{Pseudointima Appearance}

Throughout our experiments we have emphasized the use of human cells, since the ultimate usefulness of pseudointimal lined tubes lies in man. The WI-38 cell line, derived from fetal human lung, has been widely used for biological testing and in studies of population dynamics and aging. ${ }^{42-45}$ We have 


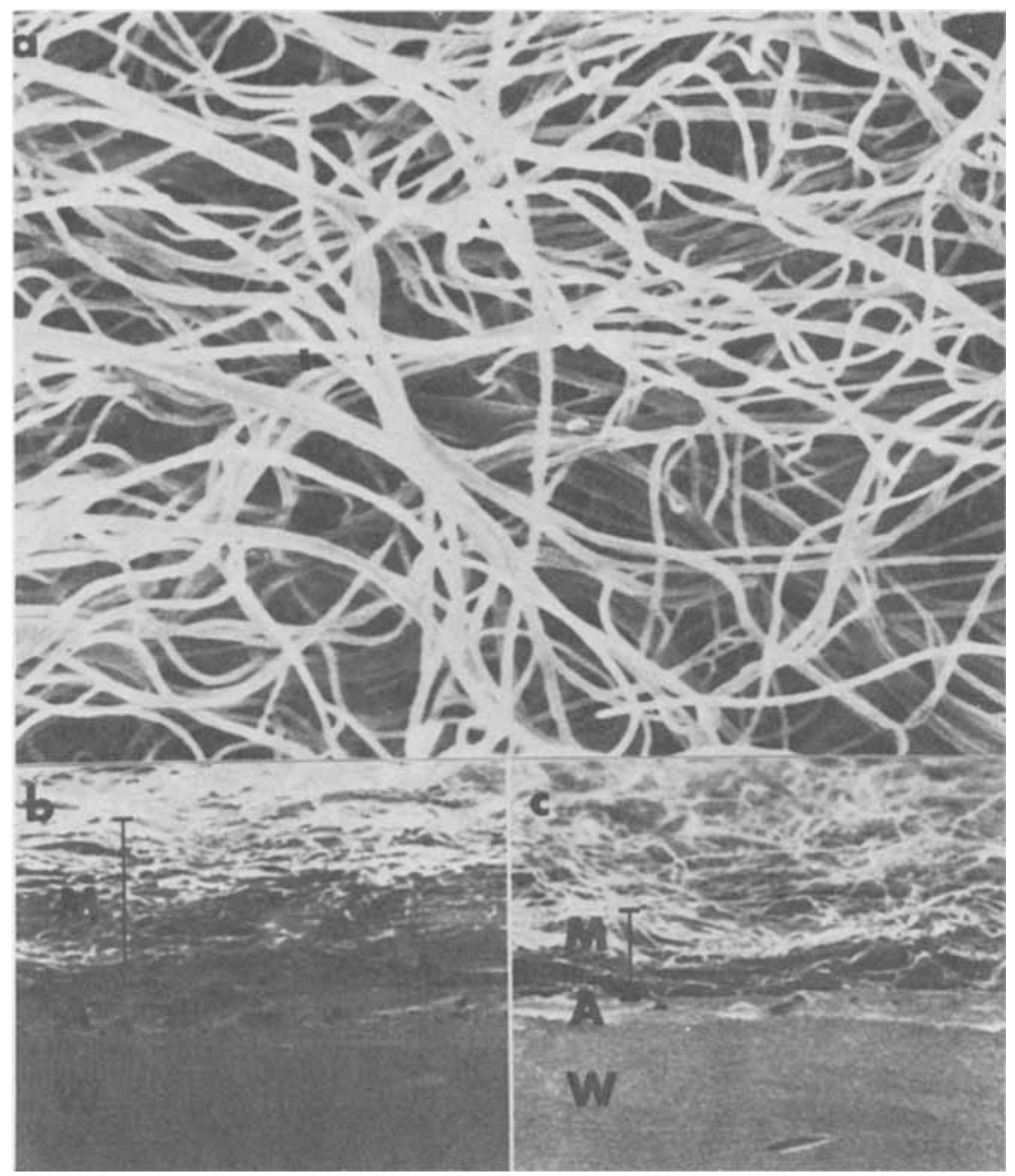

FIgURE 3. Parylene-C coated polypropylene microfiber scaffold. $a=$ Surface $(\times 1400) ; b=$ cross section of nonvertically drafted mat showing thickness of microfiber mat $(M)$ and attachment to the impermeable estane backing (W) by adhesive (A) $(\times 140) ; c=$ cross section of a vertically drafted microfiber scaffold $(\times 140)$. Note the thinner fiber mat $(M)$ and relative looseness of fibers in comparison to the nonvertically drafted mat. 


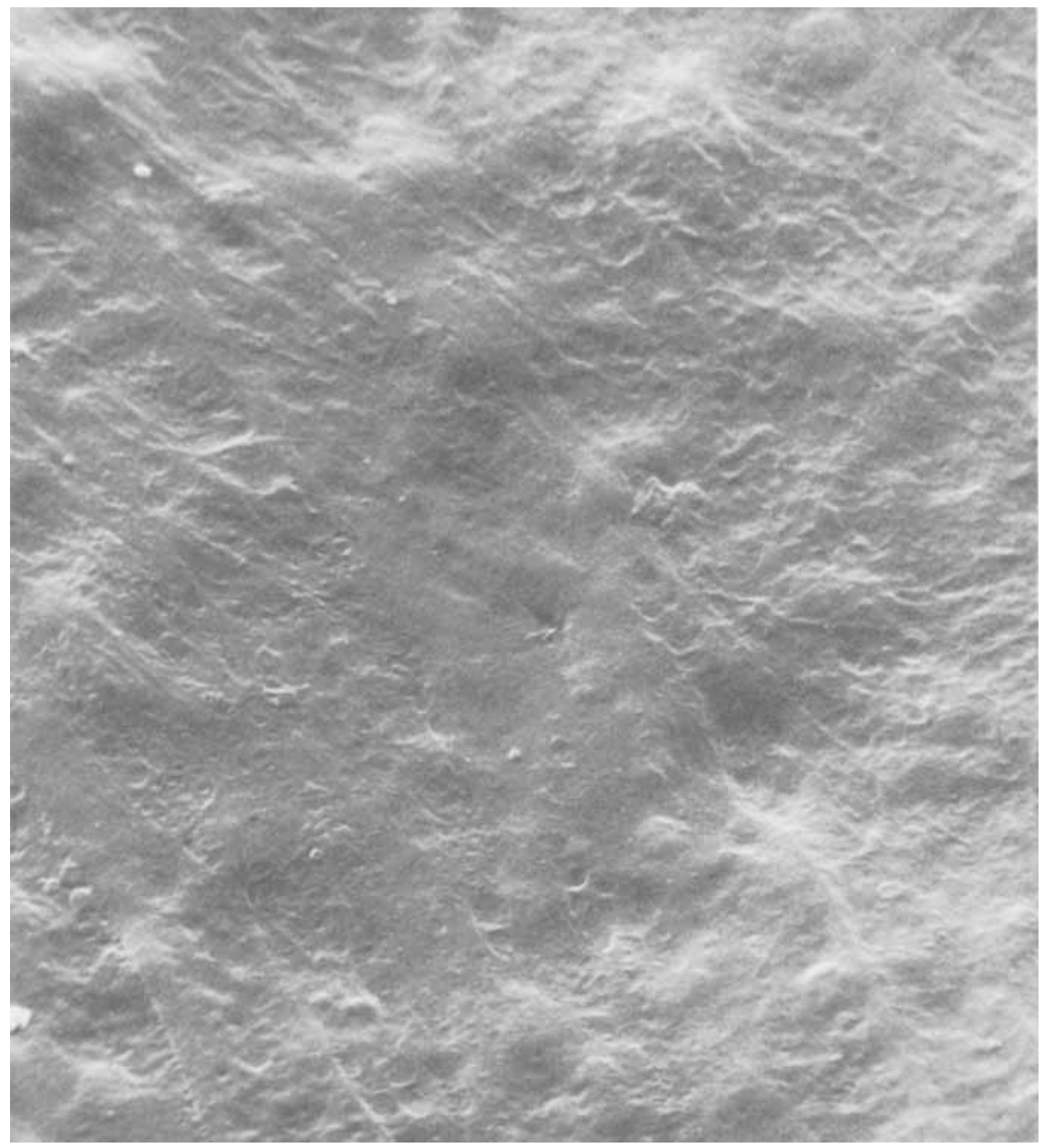

FIGURE 4. Pseudointima produced by WI-38 cells on polyester microfiber scaffold $(\times 2600)$.

found this cell line very useful for testing biocompatibility of materials and for developing techniques. ${ }^{25-2 i}$ Technically, WI-38 cells produced excellent, complete pseudointimas when seeded into microfiber scaffolds (Figure 4). However, the immune reaction of the recipient against such a cell line mitigates against its use in clinical situations. We therefore experimented with three relatively easily obtained, potentially autologous human cells for the production of pseudointimas, namely, epidermis, endothelium, and urothelium.

Because of the ease of acquisition and their abundance, epidermal cells represent perhaps the most potentially useful cells for lining prostheses. Like WI-38 cells, human epidermally derived cells produce excellent pseudointimas 
in vitro (Frgure 5). They are smooth, confluent, and usually consist of one to four layers of cells (FIGURE 6), after seven days in culture.

Theoretically, endothelium would appear to be the most desirable for lining prostheses because of its inherent blood compatibility. These cells produce excellent pseudointimas (FIGURE 7). The difficulties in rapidly propagating sufficient cells from adult human endothelium, however, limits their potential usefulness at this time.

Although urothelium (particularly from bladder) is available in limited quantities, it can be obtained in amounts adequate to seed small vessels if cultivation time is sufficient. The limited number of experiments that have been done with this cell source seems to indicate that these cells will also produce confluent cell layers on prostheses if enough cells are seeded (FIGURE 8).

\section{Microfiber Compatibility}

Compatibility of microfiber scaffolds was evaluated by seeding various fabrics with the WI-38 cells and assessing the percentage of the surface area covered with cells after seven days in vitro. As can be seen from TABLE 1, nylon 6,6 fabric (Abcor) gave better pseudointimas (69\% coverage) without

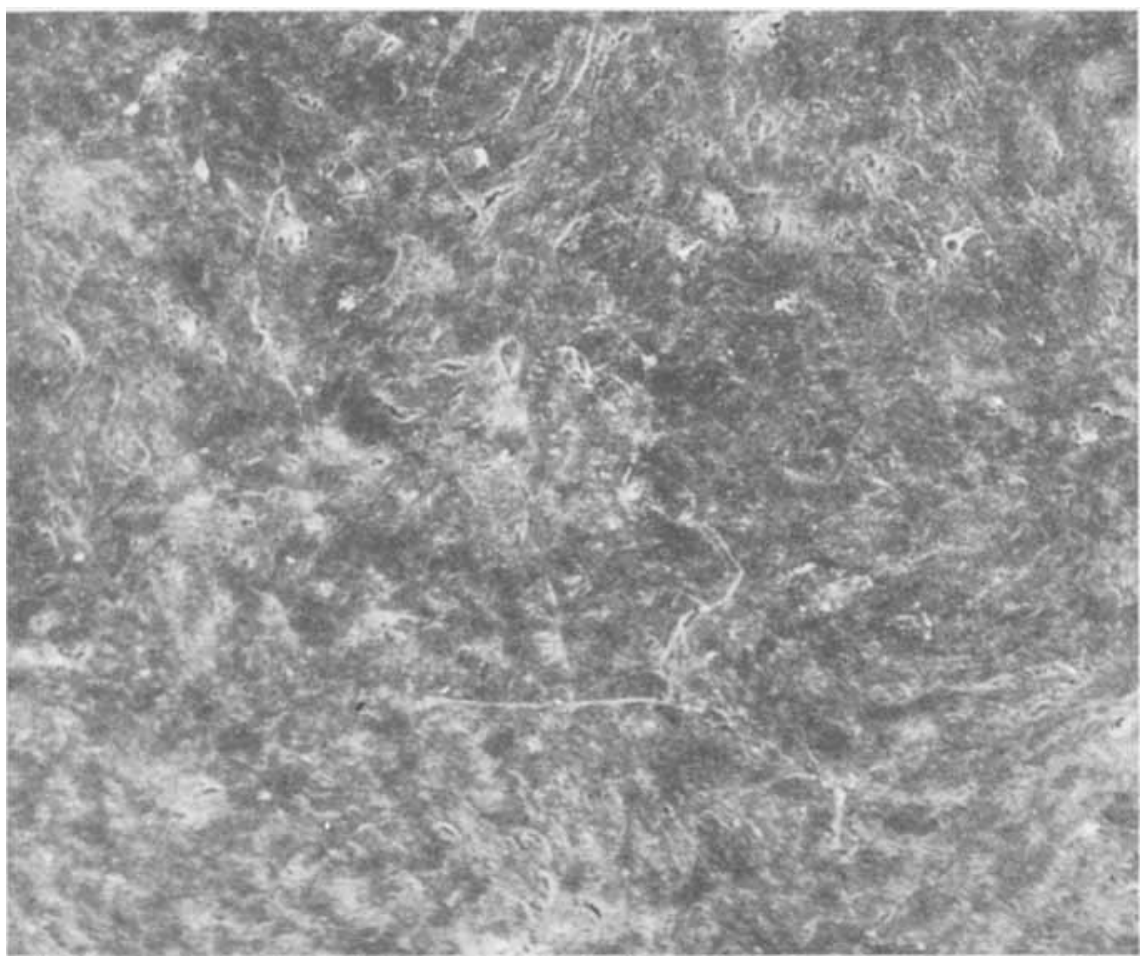

FIgure 5. Surface of a pseudointima produced by human epidermal cells on polyester microfabric $(\times 180)$. 


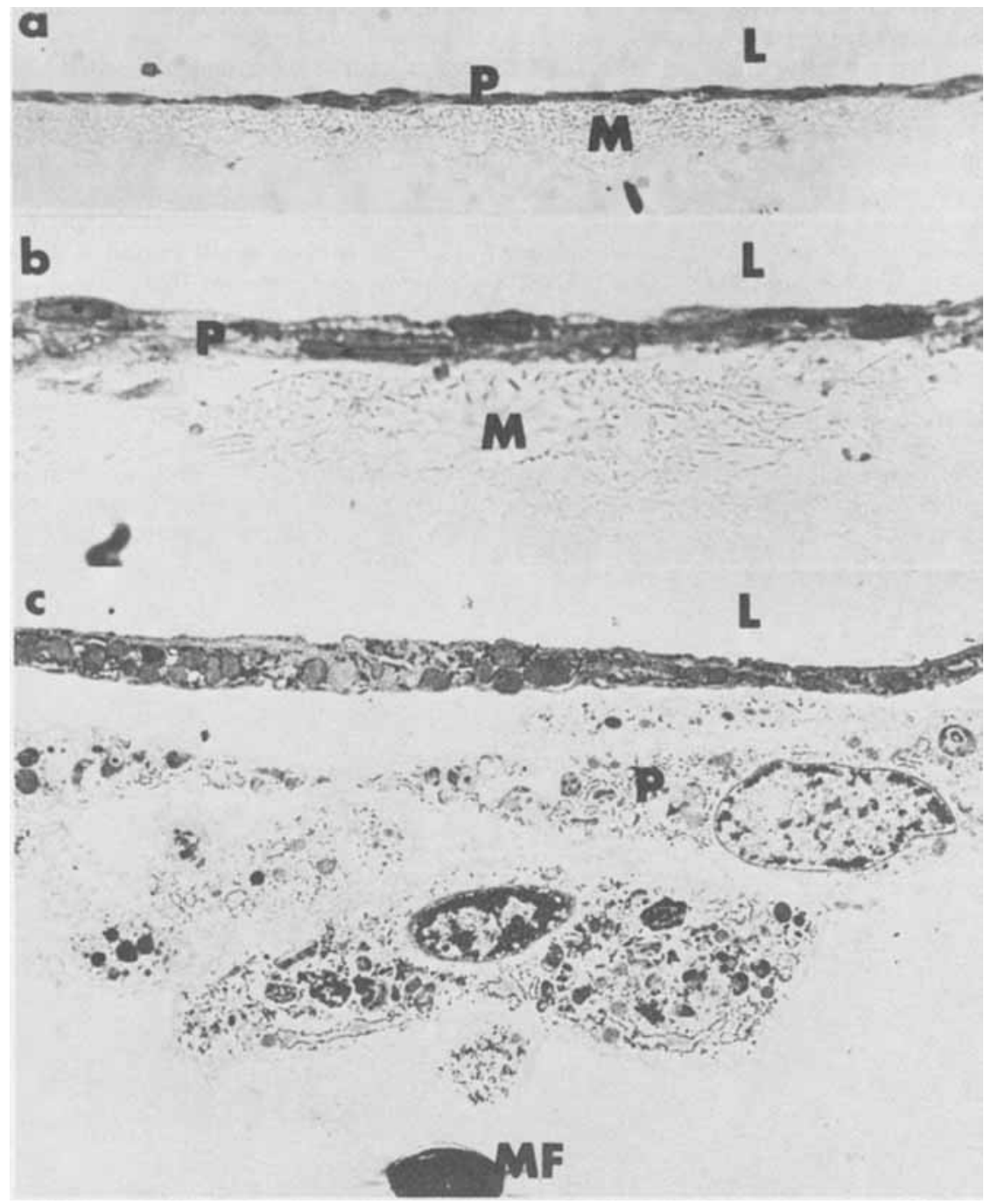

FiguRE 6. $a+b=$ Cross section of a pseudointima $(P)$ produced by human epidermal ceils on nonvertically drafted polypropylene microfibers $(M)(\times 150 ; 500)$; $\mathrm{c}=$ electron micrograph of a portion of a similar pseudointima. Note that cells at the luminal surface (L) are flattened, whereas the deeper cells near the microfiber (MF) are polygonal $(\times 3500)$,

a negative surface charge imparted by microwave discharge treatment. Carbon or Parylene-C coating of nylon (FIGURE 9) gave a dramatic improvement in coverage (100\% and $93 \%$, respectively). Parylene-C coated polypropylene fibers, whether vertically $(71 \%$ coverage) or nonvertically drafted $(71 \%$ coverage) gave slightly poorer results, but still produced good pseudointimas. The 
polytetramethylene terephthalate fabric with no special treatment or coating gave $77 \%$ coverage. It was apparent from these early experiments that carboncoated nylon was the best pseudointimal substrate. However, transmission electron microscopy showed the carbon coating to be brittle (FIGURE 10) and subject to phagocytosis. Coupled with the known, limited life span of nylon in vivo, these findings led to the exclusion of all of the nylon fabrics for studies with potentially autologous cell lines.

Fabric coverages with epidermal, endothelial, and urothelial cells are shown in TABLE 2. Epidermal cells grew well on all of the fabrics tested, whereas endothelial and urothelial cells did considerably worse on the Parylene-C coated polypropylene. From the results of these and of the WI-38 experiments it is

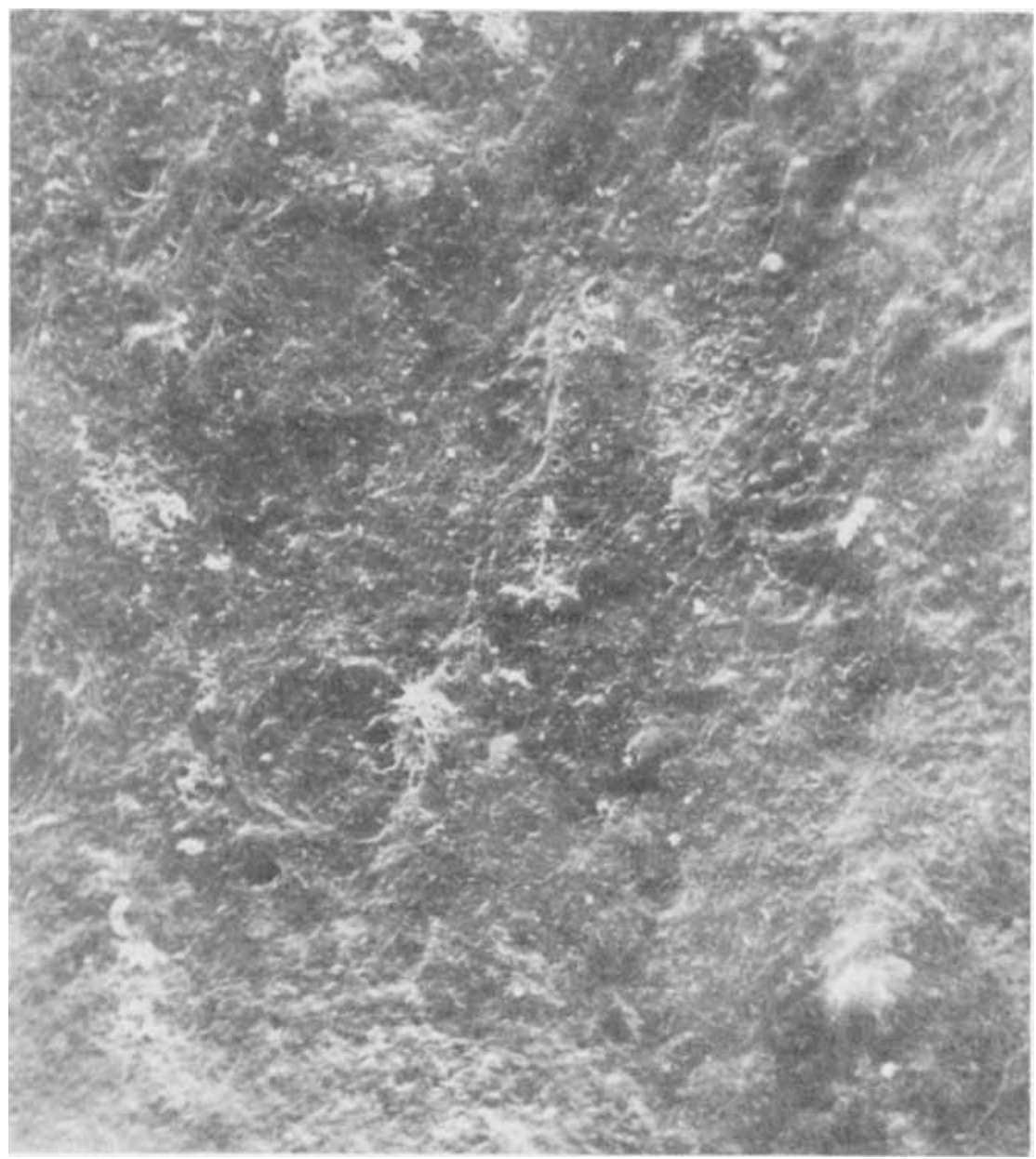

FIgure 7. Surface view of a pseudointima produced by human endothelial cells on a polyester microfiber scaffold $(\times 1400)$. 
apparent that the polytetramethylene terephthalate microfibers offered the best substrates for pseudointimal development with the cell lines which we have tested. These microfiber scaffolds have the additional advantage of being firmly embedded (FIGURE $2 \mathrm{~b}$ ) in the estane backing and therefore are resistant to shearing forces.

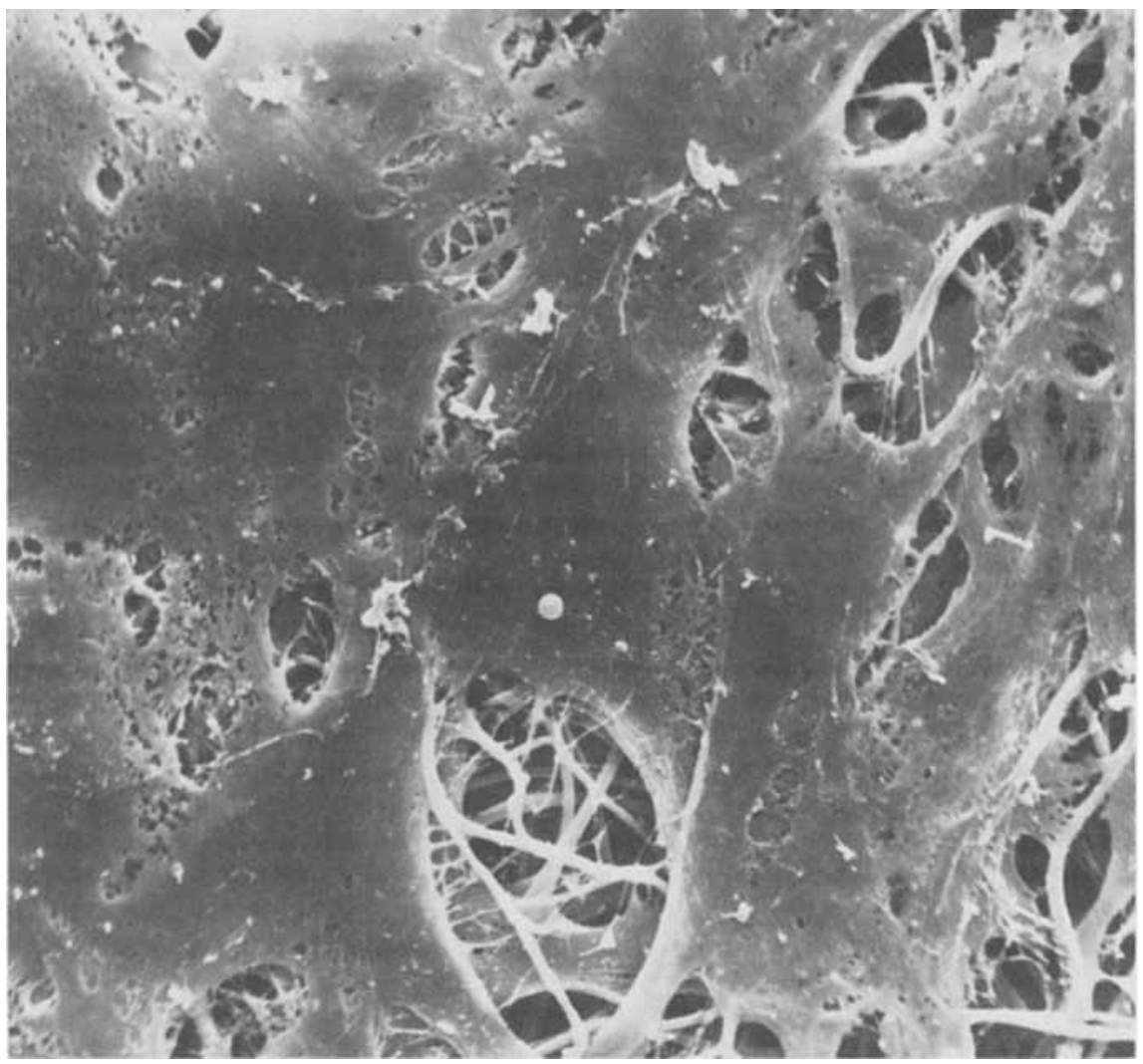

FIGURE 8. Pseudointima produced by urothelium on polyester microfibers. The cell layer is incomplete in this specimen because not enough cells $/ \mathrm{mm}^{2}$ were seeded $(\times 1100)$.

Also important in the development of pseudointimas in vitro was the culture system used (TABLE 3 ). Devices cultivated in roller bottles by perfusion require significantly fewer cells $/ \mathrm{mm}^{2}(\mathrm{p}<.05)$ to give $80-100 \%$ coverage within seven days when compared to static cultures under the same conditions. Similarly, perfusion culture requires the least number of cells $/ \mathrm{mm}^{2}$ to give the same coverage. 
Burkel \& Kahn: Microfiber Scaffolds

TABLe 1

Microfiber Compatibility with WI-38 Cells

\begin{tabular}{|c|c|c|c|c|}
\hline \multirow{2}{*}{$\frac{\text { Fiber Type }}{\text { Nylon } 6,6+}$} & \multirow{2}{*}{$\begin{array}{l}\begin{array}{l}\text { Coating or } \\
\text { Treatment }\end{array} \\
-\end{array}$} & \multirow{2}{*}{$\frac{\begin{array}{c}\text { Number of } \\
\text { Experiments }\end{array}}{(30)}$} & \multicolumn{2}{|c|}{$\begin{array}{c}\text { Mean } \% \text { of Surface } \\
\text { Area Covered }\end{array}$} \\
\hline & & & 69 & 30.9 व \\
\hline Nylon-6,6† & Microwave & (18) & 54 & 47.7 I \\
\hline Nylon-6,6 $\dagger$ & Parylene-C & (13) & 93 & 8.59 \\
\hline Nylon-6, 6t & Pyrolytic Carbon & (6) & 100 & $0.0 \rrbracket$ \\
\hline \multicolumn{5}{|l|}{ Polytetramethylene } \\
\hline Terephthalate $\dagger$ & — & (48) & 77 & $28.9 \pi$ \\
\hline Polypropylene- & Parylene-C & & & \\
\hline Non-Vert. Draft $\ddagger$ & Microwave & (90) & 71 & 34.6 \\
\hline Polypropylene Vert. & Parylene-C $\ddagger$ & & & \\
\hline Draft $\ddagger$ & Microwave & (75) & 71 & 37.8 ๆ \\
\hline
\end{tabular}

$*(\quad)=$ Number of cases.

$\dagger$ Abcor, Inc.

¥ Union Carbide, Corp.

$\$$ Gulf Atomic, Inc.

I Standard deviation throughout column.

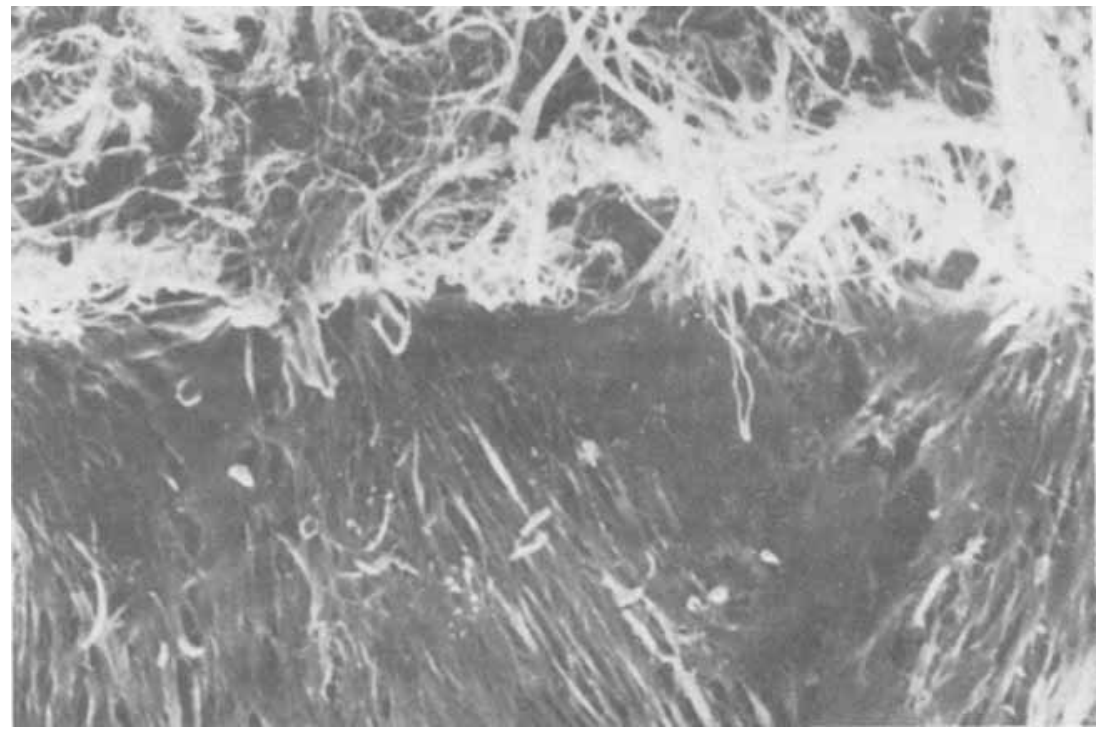

FIgure 9. Pseudointima produced by WI-38 cells on a nylon 6,6 fabric only partly coated with carbon. The carbonized portion (below) is very compatible to, and almost completely covered with cells which are almost totally absent on the bare nylori above $(\times 200)$. 


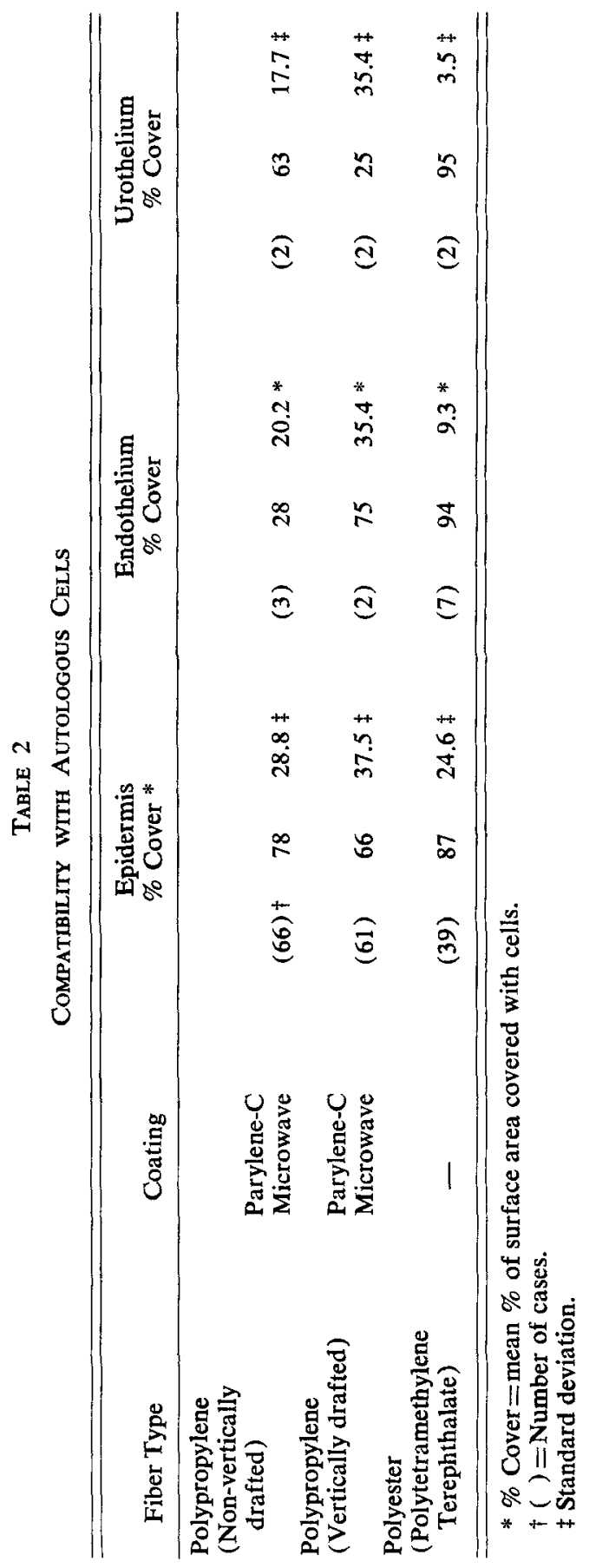




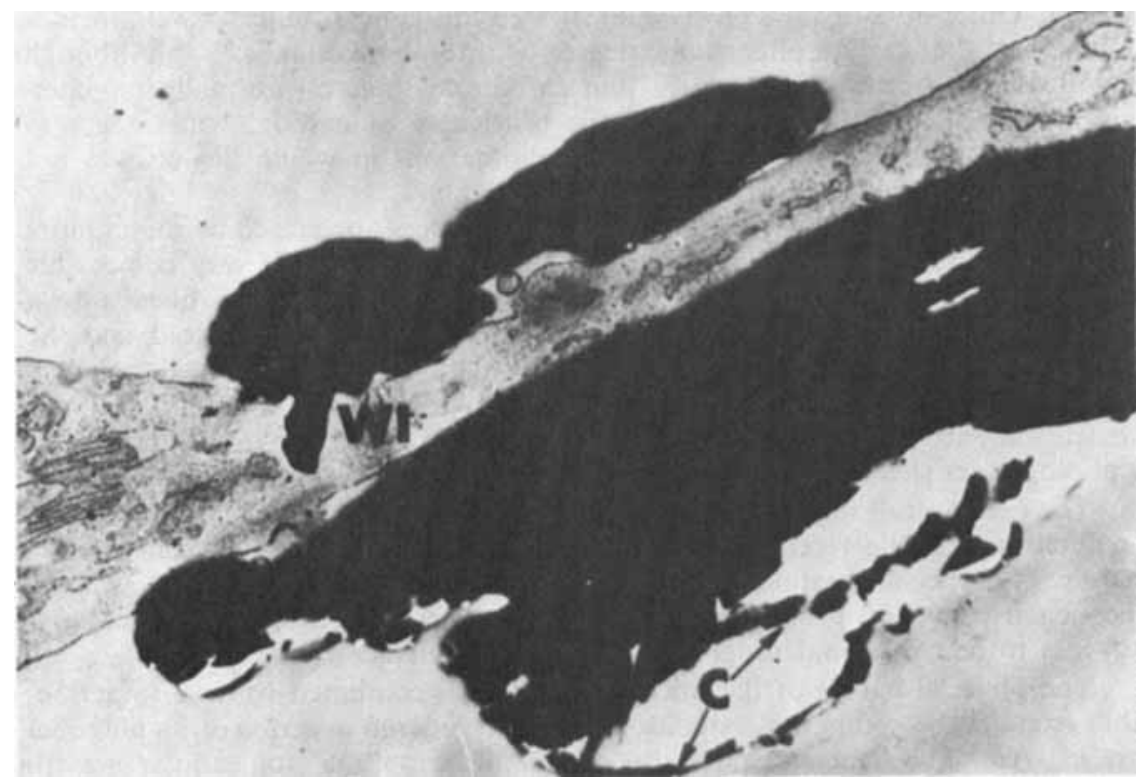

FIgURE 10. Transmission electron micrograph of carbon-coated nylon fibers on either side of a WI-38 cell (WI). Note that the carbon layer (C) has become fractured at the surface of the microfiber $(\times 13,000)$.

\section{Discussion}

The use of cell-lined microfiber scaffolds as blood interfaces depends upon (1) microfibers that are compatible with cells and durable in vivo: (2) the availability of nonthrombogenic, nonantigenic cells to line prostheses and the (3) tissue culture technology capable of cultivating suitable cells and producing reliable pseudointimas.

The present study demonstrates that tissue culture can provide a rapid and inexpensive procedure to screen materials and that there are wide differences in the biocompatibility of microfiber scaffolds to cultured cells in vitro. Carboncoated fabrics are without question the best surface for cell growth encountered

TABLE 3

Comparison of Culture Methods

\begin{tabular}{|c|c|c|c|c|c|c|c|}
\hline \multirow{3}{*}{\begin{tabular}{c}
\multicolumn{1}{c}{$\begin{array}{c}\text { Cell } \\
\text { Type }\end{array}$} \\
\\
WI-38 \\
Epidermis
\end{tabular}} & \multicolumn{3}{|c|}{$\begin{array}{l}\text { Mean number of cells } / \mathrm{mm}^{2} \\
\text { yielding } 80-100 \% \text { coverage }\end{array}$} & \multicolumn{4}{|c|}{$\begin{array}{l}\text { Minimum number of cells } / \mathrm{mm}^{2} \\
\text { yielding } 80-100 \% \text { coverage }\end{array}$} \\
\hline & Static & \multicolumn{2}{|c|}{ Perfusion } & \multicolumn{2}{|c|}{ Static } & \multicolumn{2}{|c|}{ Perfusion } \\
\hline & $\begin{array}{cc}(119) * & 11980 \\
(50) & 9108\end{array}$ & $\begin{array}{l}(64) \\
(44)\end{array}$ & $\begin{array}{l}9146 \\
5267\end{array}$ & $\begin{array}{r}(119) \\
(50)\end{array}$ & $\begin{array}{l}5100 \\
5600\end{array}$ & $\begin{array}{l}(64) \\
(44)\end{array}$ & $\begin{array}{l}2480 \\
1840\end{array}$ \\
\hline
\end{tabular}

$*(\quad)=$ Number of cases. 
to date. Other investigators have demonstrated this compatibility as well, including the fact that carbon offers some degree of thromboresistance. ${ }^{37,38}$ Although it is possible to produce extremely thin carbon coatings on normally noncompatible microfibers (i.e. nylon 6,6), the brittleness of carbon would seem to preclude its use; the exception being those situations in which flexion was not required, such as in heart valves.

The use of Parylene- $\mathrm{C}$ as a coating for microfibers appears to be much more satisfactory in terms of flexibility than carbon. Moreover, it is very compatible with cells and has the additional advantage of binding all of the fibers into a continuing web, thereby providing structural integrity of the scaffold and the backing. The long-term durability of this material in vivo, however, is unknown. We have some concern that these microfiber scaffolds might separate from the vessel wall at the point of adhesion (FIGURE 3) or between layers of the scaffold, under shearing forces encountered at systole.

The best overall microfiber scaffold tested so far appears to be the polyester (polytetramethylene terephthalate). This material gives excellent cell growth, requires no special treatment, and is firmly embedded into the vessel wall by the negative casting procedure. The only drawback of this type of material appears to be occasional roughness of the inner surface of the fabric.

The physical nature of the microfiber scaffolds combined with an impermeable estane wall used in these studies must be considered in terms of its potential use in vivo. The fiber and pore size appear to be optimal for cellular growth and penetration. The nonporous outer wall has direct applicability to blood pumps but is less useful in arterial or venous replacement because of its relative inflexibility and exclusion of transinterstices growth. Ideally, it may be useful to produce a vessel with a microfiber scaffold attached to a biodegradable outer wall. This wall would prevent hemorrhage after implantation but would subsequently permit gradual replacement with connective tissue cells and ingrowth of blood vessels to the pseudointima. Ultimately, only the microfiber scaffold would remain as a supporting skeleton for the pseudointima and the connective tissue wall.

Cell sources for nonthrombogenic, nonantigenic pseudointimal linings must take into account ease of acquisition, numbers of cells available, adaptability to the in vitro environment, rapidity of growth, and their in vivo behavior. From a technical point of view, the WI-38 cells used for establishing biocompatibility form excellent pseudointimas in vitro and are very durable in simulated vascular systems. ${ }^{31,32}$ Yet, they would not be useful in vivo, since they are allogenic and, most likely, thrombogenic. While other investigators have used a variety of connective tissue cells, ${ }^{19,20,46}$ they all required a fibrin coagulum. In one series of experiments Bernhard et al. ${ }^{46}$ were able to use allogenic fetal fibroblasts to produce pseudointimas in calves without rejection. It is doubtful, however, that such allogenic cells would survive in other species or in adult cattle, for that matter. Rapidly growing fetal cells for pseudointimas would be useful only clinically if they were found to be nonthrombogenic and the immune response were lacking or could be suppressed without threat to the host. Since this is unlikely at the present time, potentially autologous cell lines seem to be the more reasonable approach.

The ease of acquisition and abundance of epidermis makes this a useful cell type for pseudointimal production. Skin fragments were used by Adachi et al. ${ }^{20}$ to produce pseudointimas, but they found that fragments yielded rough surfaces and an irregular distribution of cells. Their attempts at producing pseudointimas 
from subcultured skin were unsuccessful. In these studies, cultivated epidermal cells produce excellent pseudointimas of one to four layers of cells in vitro. While demonstrating structural differences depending upon their position, epidermal cells appear to modulate in their new environment and have never exhibited any keratinization. The question, however, remains as to whether these pseudointimas are nonthrombogenic. Preliminary studies indicate that the epidermal cells we have used are less thrombogenic than fibroblasts. ${ }^{47}$ However, further studies are required and are currently under-way with canine epidermis.

Although a natural endothelium would appear to be ideal because of its natural nonthrombogenicity and relative ease of acquisition from subcutaneous veins, culture of these cells is beset with technical problems. The first problem relates to the derivation of cells and the second to their slow growth in vitro, which appears to be only slightly faster than in vivo. Numerous investigators have cultivated fetal endothelial cells from human umbilical cord ${ }^{48-54}$ and have used these cells extensively to study the properties of endothelium. These cells, however, are far different from adult endothelium in their adherence to underlying connective tissue and their growth characteristics. ${ }^{55}$ To be sure, adult endothelium grows very slowly in man, as is shown by healing rates of prostheses. ${ }^{4,56}$ Moreover, arterial and venous endothelium differ structurally from each other, as does the endothelium of either of these vessels in different parts of the same animal. ${ }^{57}$

Although cells derived from adult human endothelium do produce confluent pseudointimal linings for prostheses (FIGURE 7), their ultimate use in clinical situations will depend upon the ability to enhance their proliferation. Perhaps adult endothelium requires a mitotic stimulant such as the "tumor angiogenesis factor," 58 for, to our knowledge, no one has successfully cultivated adult human endothelial cells in quantity. Other investigators $19,20,22$ have used pieces of blood vessels to produce pseudointimas, but whether the linings produced were of endothelial, smooth muscle, or connective tissue origin is unknown. Mansfield et al. ${ }^{34}$ has shown excellent pseudointimas produced in vitro with calf endothelial cells, and this work holds some promise. Whether it can be extrapolated to human tissue, however, remains a question, since calf endothelium is relatively easy to propagate in vitro and calves are known to coat naked prostheses quite rapidly. ${ }^{4}$ Clearly, the calf is not the closest experimental model for man. ${ }^{4}$

The use of urothelial cells to produce pseudointimas is questionable at this time. That these cells will line prostheses in vitro is apparent. These cells proliferatae quite rapidly, but their usefulness is limited by the small amounts of tissue that may be obtained for culture. Consequently, they would be useful to line small prostheses, and then only if they are found to be nonthrombogenic.

The advantages of perfusion over static cultures have been consistently demonstrated in this investigation. In all experiments we were able to produce comparable pseudointimas by perfusion culture with only $70 \%$ of the cells required to seed materials cultured under static conditions. These results corroborate those of Kruse et al..$^{5-61}$ in the production of multiple-layered populations of cells. The improvement in results in perfusion culture relate not only to the steady state of the media nutrients, but also to the periodic exposure of the pseudointimas to air as the tubes rotate, thus providing oxygenation.

The quality and completeness of pseudointimas produced also varies with the method of seeding the cells into the fabric. Various techniques have been employed, from simply pouring cells onto the surface of flat or concave de- 
vices, ${ }^{35}$ to culturing tubes in a closed container with cells for a few hours, ${ }^{46}$ to the elaborate seeding devices of Ghidoni et al., ${ }^{62}$ to the centrifugation and stabilization methods which we have employed.2T, 32 Even more complicated techniques will be necessary to seed and culture irregular shaped prostheses such as bifurcated tubes and specialized heart pumps.

It must be emphasized that tissue culture technology applied to the production of cellular blood interfaces varies with the type of prosthesis and the cell line used. Different cell types will have specific requirements for their optimal derivation and cultivation in vitro. Equally important, the effects of culture media, nutrient turnover, temperature, osmolality, gaseous environment, water quality, and materials used in cell handling will all influence viability, growth, and pseudointima development. ${ }^{22}$

\section{SUMMARY}

In an attempt to develop blood-compatible interfaces, cells were cultivated in vitro on microfiber scaffolds lining nonporous vascular prostheses and discs. The scaffolds were fabricated as nonwoven meshes of nylon and polyester (polytetramethylene terephthalate) (Abcor, Inc.) or polypropylene (Union Carbide, Inc.). Microfibers ranged from 0.2 to $2 \mu \mathrm{m}$ in diameter. The fibers were left bare, microwave discharge-treated, coated with carbon, Parylene- $\mathrm{C}$, or combinations of these. WI-38 cells were used to test biocompatibility and potentially autologous human cell lines (epidermal, endothelial, and urinary tract epithelium) were used to produce pseudointimas. Tubes and discs were washed and degassed, seeded with cells by centrifugation, stabilized in a confined environment, and cultivated by roller bottle perfusion or in Falcon tissue culture flasks. WI-38 cells produced 54-100\% coverage, depending on the microfiber composition. Epidermal cells yielded excellent pseudointimas with the polyester microfibers as the best overall substrate and nylon microwave-treated fibers as the least effective. Adult human endothelium produced coverages of $28-94 \%$, while urothelium provided the poorest pseudointimas.

\section{ACKNOWLEDGMENTS}

The authors wish to express their appreciation to Mrs. Ruth Sell, Mrs. Irene Loo, Ms. Rosalie Beer, Mrs. Maxine Chapo, and Mr. Richard Klann for their valuable assistance.

\section{REFERENCES *}

1. BRUCK, S. D. 1972. Macromolecular aspects of biocompatible materials-A review. J. Biomed. Mater. Res. 6: 173-183.

2. Bruck, S. D. 1972. Biomaterials in medical devices. Trans. Am. Soc. Artif. Intern. Organs 18: 1-7.

3. Wesolowski, S. A., C. C. Fries, K. E. Karlson, M. Debakey \& P. N. Sawyer. 1961. Porosity: primary determinant of ultimate fate of synthetic vascular grafts. Surgery 50: 91-96.

4. FRY, W. J., M. S. Deweese, R. O. Kraft \& C. B. Ernst. 1964. Importance of porosity in arterial prostheses. Arch. Surg. 88: 836-842.

* References identified as "Annual Reports" can be obtained from the National Technical Information Service, 5285 Port Royal Road, Springfield, Virginia 22151. 
5. Wesolowski, S. A., W. M. Golaski, L. R. Sauvage, J. D. McMahon \& Y. Комото. 1968. Consideration in the development of small artery prostheses. Trans. Am. Soc. Artif. Intern. Organs 14: 43-47.

6. Wesolowski, S. A., C. C. Fries \& J. D. McMahon. 1968. Arterial prosthetic materials. Ann. N.Y. Acad. Sci. 146: 325-344.

7. Sauvage, L. R., K. E. Berger, S. J. Wood, S. G. Yates II, J. C. Smith \& P. B. MANSFIELD. 1974. Interspecies healing of porous arterial prostheses. Observations, 1960 to 1974. Arch. Surg. 109: 698-705.

8. Benson, R. W., D. D. Payne \& J. A. Deweese. 1975. Evaluation of prosthetic grafts of different porosity for arterial reconstruction. Am. J. Surg. 129: 665669.

9. Wesolowski, S. A., C. C. Fries, J. D. McMahon \& A. Martinez. 1966. Evaluation of a new vascular prosthesis with optimal specifications. Surgery 59: 40-56.

10. Sauvage, L. R., K. Berger, S. J. Wood, A. A. SAmeh, A. S. Wesolowski, W. M. Golaski, M. Demonenico \& J. R. Hartmann. 1969. A very thin, porous knitted arterial prosthesis; experimental data and early clinical assessment. Surgery 65: 78-88.

11. Buxton, B. F., D. C. Wukasch, C. Martin, W. J. Liebig, G. L. Hallman \& D. A. Cooley. 1973. Introduction of a new bifurcated graft. Am. J. Surg. 125: 288-293.

12. Nuwayser, E. S., S. Bonacci, J. Knudsen, R. Tuelings \& S. Davis. 1969. Research on materials compatible with blood. In Proc. Artificial Heart Program Conference : 153-168. U. S. Government Printing Office. Washington, D.C.

13. Nuwayser, E. S. 1971. Microfiber substrate development. Ann. Rpt. Contract no. NIH-71-2047, National Heart and Lung Institute, Bethesda, Md. PB 206 758.

14. Byck, J. S., W. A. Miller, M. A. Spivack, L. J. Gonsior, V. Z. Williams, JR., B. P. Barth, H. D. Bassett, R. K. Dearing, J. F. GaAsch, D. L. Schober, D. D. Stewart \& F. R. Tittman. 1970. Polymeric materials for circulatory assist devices. Ann. Rpt. Contract no. PH-43-68-1388, National Heart and Lung Institute, Bethesda, Md. 20014.

15. Liotta, D., C. W. Hall, A. Villanueva, R. M. O'Neal \& M. E. Debakey. 1966. A permanent autologous lining for implantable blood pumps: A pseudoendocardium. Cardiov. Res. Cent. Bull. 4: 69-80.

16. Ghidoni, J. J., D. Liotta, C. W. Hall, R. M. O'Neal \& M. E. Debakey. 1968. In Vivo culture of tissue fragments which produce viable cellular linings covered by endothelium (neointimas) in impermeable, velour-lined arterial prostheses, bypass pumps, and valvular prostheses. Trans. Am. Soc. Artif. Organs 14: 69-72.

17. Ghidoni, J. J., D. Liotta, C. W. Hall, J. G. Adams, A. Lechter, M. BarrioNueva, R. M. O'Neal \& M. E. Debakey. 1968. Healing of pseudointima in velour-lined impermeable arterial prostheses. Am. J. Path. 53: 375-383.

18. Ghidoni, J. J., D. Liotta, C. W. Hall, R. M. O'Neal \& M. E. Debakey. 1968. Production of cellular linings in impermeable velour-lined cardiovascular prostheses: Growth from implanted tissue fragments. Surgery 65: 70-77.

19. Adachi, M., M. Suzuki \& J. H. Kennedy. 1970. Preoperative coating of velourlined circulatory assist devices with fibrin coagulum membrane (FCM). Trans. Am. Soc. Artif. Int. Organs 16: 7-11.

20. AdACHI, M., M. SuzukI \& J. H. KenNEDy. 1971. Neointimas cultured in vitro for circulatory assist devices: I. Comparison of cultured cells derived from autologous tissues of various organs. J. Surg. Res. 11: 483-491.

21. Nomura, Y. 1970. The ultra-structure of the pseudointima lining synthetic arterial grafts in the canine aorta with special reference to the origin of the endothelial cell. J. Cardiovas. Surg. 11: 282-291.

22. Mansfield, P. B. and A. Wechezak. 1968. Tissue cultured cells as an endo- 
thelial lining of prosthetic materials. Organ Perfusion \& Preservation. J. C. Norman, Ed. : 189-201. Appleton-Century-Crofts, New York, N.Y.

23. Schultz, L., R. Grobstein, B. S. Bull \& N. S. Braunwald. 1969. Reconstruction of differentiated tissue layers from dissociated cells: Use of tissue culture techniques to develop nonthrombogenic autologous cell surfaces for use as cardiac linings. Ann. Rpt no. PB 43-68-1378-02. National Heart Institute, NIH, Bethesda, Md. 20014.

24. Schultz, L., B. S. Bull \& N. S. Braunwald. 1971. Use of tissue culture techniques to evaluate new materials developed to serve as artificial heart linings. Surgery 69: 557-562.

25. KaHN, R. H. 1971. Multiple-layered intimal linings by perfusion. Annual Rept. no. NIH 71-2054-01, Medical Devices Applications Program, National Heart and Lung Institute, NIH, Bethesda, Md. 20014.

26. KAHN, R. H. \& W. E. BuRKeL. 1972. Multiple-layered intimal linings by perfusion culture. Ann. Rpt. no. NIH 71-2054-02, Division of Technological Applications, National Heart and Lung Institute, NIH, Bethesda, Md. 20014.

27. KahN, R. H. \& W. E. Burkel. 1973. Propagation of pseudointimal linings of vascular prostheses. In Vitro 8: 451-458.

28. Nuwayser, E. S., P. B. Mansfieid, A. Wechezak, R. H. KahN, W. E. Burkel \& J. B. Boatman. 1973. Cultured linings for vascular assist devices. Trans. Am. Soc. Artif. Int. Organs. 19: $168-174$.

29. KahN, R. H. \& W. E. Burkel. 1973. Multiple-layered intimal linings by perfusion culture. Ann. Rpt. no. NO-1-2054-7, Biomaterials Program, Thrombosis and Hemorrhagic Diseases Branch, Division of Blood Diseases and Resources, National Heart and Lung Institute, NIH, Bethesda, Md. 20014.

30. WechezaK, A. R. \& P. B. Mansfield. 1973. Isolation and growth characteristics of cell lines from bovine venous endothelium. In Vitro 9: 39-43.

31. KAHN, R .H. \& W. E. BuRKEL. 1974. Multiple-layered intimal linings by perfusion culture. Ann. Rpt. no. 1-HB-2054-4, Biomaterials Program, Division of Blood Diseases and Resources, National Heart and Lung Institute, NIH, Bethesda, Md. 20014.

32. KahN, R. H., W. E. Burkel \& V. P. Perry, 1974. Homeostatic and mass culture technology. J. Nat. Cancer Inst. 53: 1471-1477.

33. Kahn, R. H., W. E. Burkel \& J. C. Stanley. 1975. Development and testing of pseudointimal-lined vascular prosthetic devices. Ann. Rpt. NIH no. 1-HB1-2054, Biomaterials Program, Division of Heart and Vascular Disease, National Heart and Lung Institute, NIH, Bethesda, Md. 20014.

34. Mansfield, P. B., A. R. Wechezak \& L. R. Sauvage. 1975. Preventing thrombus on artificial vascular surfaces: True endothelial cell linings. Trans. Am. Soc. Artif. Int. Organs. 21: 264-272.

35. Eskin, S. G. \& L. Trevino. 1976. Aortic endothelial cells and smooth muscle cells cultured on cardiovascular biomaterials. 9th Ann. Scanning Electron Microscopy Symp. Illinois Institute of Technology Research Inst. Chicago, Ill. In press.

36. Medzon, E. L. \& A. Gedres. 1971. Substitution of 4-(2-hydroxyethyl)-1piperazine-ethane sulfonic acid (HEPES) for bicarbonate in protein-free animal cell culture medium: application to vaccinia virus quantitation and fluorogenic acetylesterase assay in living LM cells. Ca. J. Microbiol. 17: 651-653.

37. Lagrange, L. D., V. L. Gott, J. C. Bokros \& M. D. Ramos. 1969. Compatibility of carbon and blood. Proc. Artificial Heart Program Conference R. J. Hegyeli, Ed. : 47-58. National Institutes of Health, Bethesda, Md. U.S. Government Printing Office, Washington, D.C.

38. Bokros, J. C., E. Dalle-Molle, B. D. Epstein, F. J. Schoen \& D. P. Snowden. 1971. Biocompatibility of carbon. Ann. Rpt. Contract no.. PH43-67-1411, National Heart and Lung Institute, NIH, Bethesda, Md. Ann. Rpt. PB 198-404.

39. Loeb, W. E., F. R. Tittman \& M. Goldin. 1969. U.S. Pat. 3,429,739, Feb. 25, 1966. 
40. Gorham, W. F. 1966. J. Polymer Sci. 4: 3027; U.S. Pat, 3,288,728, Nov. 29, 1966; U.S. Pat. 3,342,754 Sept. 19, 1967.

41. Byck, J. S., L. M. Baker, S. W. Chow, L. J. Gonsior, W. A. Miller, W. P. Mulvaney, L. M. Robewon, M. A. Spivack \& V. Z. Williams, JR. 1969. Polymeric Materials for Circulatory Assist Devices. Ann. Rpt. Contract no. 43-68-1388, National Heart and Lung Institute, NIH, Bethesda, Md. 20014.

42. Hayflick, L. 1965. The limited in vitro lifetime of human diploid cell strains. Exp. Cell Res. 37: 614-636.

43. Hayflick, L. 1968. Human Cells and Aging. Sci. Am. 218: 32-37.

44. SLONIM, D . 1973. Study of the population dynamics of human diploid cell strain WI-38. I. The number of cells seeded. J. Biol. Stand. 1: 305-311.

45. Slonim, D. 1974. Study of the population dynamics of human diploid cell strain WI-38. II. The composition of the medium. J. Biol. Stand. 2: 51-58.

46. Bernhard, W. F., M. Hussain, J. B. George \& G. W. Curtis. 1969. Fetal fibroblasts as a substratum for pseudoendothelial development on prosthetic surfaces. Surgery 66: 284-290.

47. Pitlick, F. Personal communication.

48. Pomerat, C. M. \& W. C. SLick. 1963. Isolation and growth of endothelial cells in tissue culture. Nature 198: 859-861.

49. Maruyama, Y. 1963. The human endothelial cell in tissue culture. Zeit. Zellf. 60: 69-79.

50. Fryer, D. G., G. Birnbaum \& C. N. Luttrell. 1966. Human endothelium in cell culture. J. Atheroscler. Res. 6: 151-163.

51. Jaffe, E. A., R. L. Nachman, C. G. Becker \& R. C. Minick. 1972. Culture of human endothelial cells derived from human umbilical cord veins. Circulation 46: 253-256.

52. Gimbrone, M. A., R. S. Cotran \& J. Folkman. 1974. Human vascular endothelial cells in culture. Growth and DNA synthesis. J. Cell Biol. 60: 673-684.

53. Haudenschild, C. C., R. S. Cotran, M. A. Gimbrone, JR. \& J. Folkman. 1975. Fine structure of vascular endothelium in culture. J. Ultra. Res. 50: 22-32.

54. Henriksen, T., S. A. Evensen, R. F. Elgjo \& A. Vefling. 1975. Human fetal endothelial cells in culture. Scand. J. Haematol. 14: 233-241.

55. Blose, S.H. \& S. CHacko. 1975. In vitro behavior of guinea pig arterial and venous endothelial cells. Dev. Growth Differ. (Nagoya) 17: 153-165.

56. Berger, K., L. R. Sauvage, A. M. RaO \& S. J. Wood. 1972. Healing of arterial prosthesis in man: its incompleteness. Ann. Surg. 175: 118-127.

57. Buss, H. 1976. Endothelial surfaces of kidney, coronary and cerebral arteries: A comparative SEM and light microscopic study. Proc. 9th Ann. Scanning Electron Microscopy Symp. Illinois Institute of Technology Research Institute. Chicago, Ill. In press.

58. Folkman, J. E. Merler, C. Abernathy \& G. Williams. 1971. Isolation of a tumor factor responsible for angiogenesis. J. Exptl. Med. 133: 275-288.

59. Kruse, P. F., JR. \& E. Miedema. 1965. Production and characterization of multilayered populations of animal cells. J. Cell Biol. 27: 273-279.

60. Kruse, P. F. M. JR., W. Whittle \& E. Miedema. 1969. Mitotic and nonmitotic multilayered perfusion cultures. J. Cell Biol. 42: 113-121.

61. Kruse, P. F., JR., L. N. Keen \& W. L. Whittle. 1970. Some distinctive characteristics of high density perfusion cultures of diverse cell types. In Vitro 6: $75-88$.

62. Ghidoni, J. J., D. Ljotta, J. G. Adams, R. M. O'Neal \& C. W. Hall. 1968. Implantation of autologous tissue fragments in velour fabric used to line cardiovascular prostheses: An In vivo culture system to produce cellular bloodprosthesis interfaces. J. Biomed. Mat. Res. 2: 201-208. 